УДК: 78.071.2:37.018.54

DOI https://doi.org/10.24919/2308-4863/41-2-45

Elena PEREVERZEVA, orcid.org/0000-0001-5497-5557 Teacher at the Department of Theory and Methodology of Music Education and Choreography Melitopol Pedagogical University named after Bogdan Khmelnytsky (Melitopol, Zaporizhzhia region, Ukraine) heloness@gmail.com

\title{
METHODOLOGICAL FUNDAMENTALS OF FORMATION OF CHOIR TEAM IN THE PROCESS OF CONDUCTOR AND CHOIR EDUCATION OF FUTURE TEACHERS OF ART
}

The article is analyzed the state of research of the problem of methodical bases of choir formation in the process of conducting and choral education, it is defined methodical concepts of choral formation, among which there are pedagogical principles of creation and management of choir and psychological and pedagogical conditions of choir formation. The article is described the stages of the forming experiment and summarizes the results of the tests of the formation of the choir.

The experimental study was conducted on the basis of Bogdan Khmelnitsky Melitopol state pedagogical university among students of I-IV courses with four stages. The method of pedagogical experiment was implemented in the disciplines "Choral class» and "Choral conducting» in the experimental group of students of I-II course of mixed Bogdan Khmelnitsky Melitopol state pedagogical university choir and based on comparative analysis tested control group of students III-IV course of the Bogdan Khmelnitsky Melitopol state pedagogical university mixed choir.

The results of the study showed the effectiveness of the implementation of the proposed methodological system of the choir formation in the process of conducting and choral education of future art teachers. The practical significance of the study is that theoretical conclusions and experimental data can serve as a basis for improving the methodological foundations of the choir formation in the process of conducting and choral education of future art teachers. The materials presented in the paper, as well as the developed methodical system of choir formation in the process of conducting and choral education of future art teachers can be used in further research on the problems of theory and methods of conducting.

Key words: higher conducting and choral education, choir, conductor, methods, pedagogical principles, psychological and pedagogical conditions.

ОЛена ПЕРЕВЕРЗЕВА,

orcid.org/0000-0001-5497-5557

викладач кафедри теорії і методики музичної освіти та хореографії

Мелітопольського держсавного педагогічного університету імені Богдана Хмельницького (Мелітополь, Запорізька область, Украӥна) heloness@gmail.com

\section{МЕТОДИЧНІ ОСНОВИ ФОРМУВАННЯ ХОРОВОГО КОЛЕКТИВУ У ПРОЦЕСІ ДИРИГЕНТСЬКО-ХОРОВОЇ ОСВІТИ МАЙБУТНІХ ВЧИТЕЛІВ МИСТЕЦТВА}

У статті проаналізовано стан дослідження проблеми методичних основ формування хорового колективу у проиесі диригентсько-хорової освіти, визначено методичні кониепти формування хорового колективу, серед яких педагогічні принципи створення і керівництва хоровим колективом та психолого-педагогічні умови формування хорового колективу. У статті описано етапи формувального експерименту та узагальнено результати контрольних зрізів сформованості хорового колективу.

Експериментальне дослідження проводилось на базі Мелітопольського державного педагогічного університету імені Б. Хмельницького серед студентів I-IV курсів і проходило в чотири етапи. Методика педагогічного експерименту впроваджувалася на дисииплінах "Хоровий клас» та "Хорове диригування» в експериментальній групі студентів I-II курсу мішаної хорової капели Мелітопольського державного педагогічного університету імені Б. Хмельницького та на основі порівняльного аналізу перевірялась контрольна група студентів III-IV курсу міманої хорової капели Мелітопольського державного педагогічного університету імені Б. Хмельницького.

Отримані результати дослідження показали ефективність впровадження запропонованої методичної системи формування хорового колективу у процесі диригентсько-хорової освіти майбутніх вчителів мистецтва. Практичне значення дослідження полягає у тому, щз теоретичні висновки й експериментальні дані можуть слугувати основою удосконалення методичних основ формування хорового колективу у процесі диригентськохорової освіти майбутніх вчителів мистецтва. Представлені в роботі матеріали, а також розроблена мето- 
дична система формування хорового колективу у процесі диригентсько-хорової освіти майбутніх вчителів мистецтва можуть використовуватись у подальших дослідженнях з проблем теорії та методики диригування.

Ключові слова: вища диригентсько-хорова освіта, хоровий колектив, диригент, методика, педагогічні приничии, психолого-педагогічні умови.

Introduction. The topicality of this problem in branch of music and music-pedagogical education is connected with insufficient development of the content of conducting training in institutions of various profiles, the lack of clear requirements for their general and special education. Most works on general and music pedagogy, history and theory of musicology, memoirs pay considerable attention to the study of the problem of choral education of choir singers. However, the peculiarities of professional conducting training remain insufficiently studied in institutions of music and pedagogical education. Elaboration of scientific works, textbooks, manuals gives the chance to analyze a pedagogical basis of conducting and choral education of music teachers of school.

Among the disciplines of the music cycle, choral class and conducting are one of the main subjects. Conducting is the most difficult to master and study, and it is also necessary in further work at school. After all, working as a music teacher, a junior specialist, as a rule, conducts extracurricular activities, organizes choirs, vocal ensembles, various musical groups, and teaching music in the classroom, he can't do without choral conducting, because each class is a small choir on the lesson. That's why, the course «Choral conducting» occupies one of important places in the cycle of special disciplines of the curriculum.

During the studying of the course «Choral conducting» in a higher pedagogical institution there is a development of many musical abilities of students. But today the level of conducting training of a music teacher is still low. One of the reasons for this situation is the lack of a clearly developed, scientifically sound system of teaching conducting in pedagogical universities. At the present stage, the professional training of future art teachers is extremely relevant, poorly developed and requires special research. Active processes of development of modern society put forward a number of new requirements for the training of teachers. Therefore, there is a constant search for ways to improve the effectiveness of music teacher training in pedagogical school.

Literature Review. There is no necessary literature on teaching choral conducting in higher pedagogical institutions. Teachers of pedagogical institutions in their educational work use mainly literature published for music schools and conservatories. The theoretical bases of conducting skill are developed in these works, the general questions of teaching of conducting are covered, great attention is paid to technique of conducting. That's why, of course, these works provide great help to teachers of pedagogical institutions. Kanerstein's M.A. book is devoted to the question of conducting skills. (Kanerstein, 1980). Modern approaches in conducting and choral training of future music teachers are considered by Kovalenko I.G. (Kovalenko, 2002). Methodical recommendations of the choir skills formation in the class of choral conducting are given by Kostenko L.V., Shumska L.Yu. (Kostenko, Shumskaya, 2005). Psychological and pedagogical aspect of conducting and choral education in higher educational institutions is covered by Smirnova T.A. (Smirnova, 2008). The monograph of Segeda N.A. is devoted to the professional development of a music teacher (Segeda, 2011). But further analysis and generalization of the theory and practice of conducting art and long-term observations of the process of teaching conducting in pedagogical institutions show that the state of teaching conducting does not meet modern requirements for music teacher and school choir conductor.

The aim of the article is theoretically substantiation and experimentally test the methodological foundations of the formation of the choir in the process of conducting and choral education of future art teachers.

Main part. Vocal and choral work is an important form of classroom and extracurricular professional activity of a music teacher at school. Therefore, one of the main tasks of studying at the Faculty of Music and Pedagogy is to prepare future teachers of music for such activities. Among the complex of special musical disciplines the basic one is "Choral class". The choir class and its teacher have important tasks: to form interest in choral singing and conducting; to develop students' vocal and choral technique necessary for singing in the choir; to develop auditory abilities, vocal and choral skills needed to work with a choir; to develop students' skills of professional and artistic performance of works; to study of different styles and genres of choral music, acquaintance with the principles of selection of choral repertoire; education of artistic taste through the study and performance of highly artistic samples of choral literature; providing students with a choral repertoire that may be necessary in their further professional activities.

Many years of experience of leading Melitopol teachers-choirmasters were analyzed, we have come 
to the conclusion that the success of the pedagogical work of the teacher-choirmaster of the institution of higher education depends on the organization of the educational process. This process is aimed at: studying a musical and choral work on the subject of determining the actuality of its inclusion in the repertoire; deep study of the work and its comprehensive analysis; conductor processing and preparation of the conductor to work with the executive team; work on the work with the performing team. In the process of developing such tasks, the teacher-choirmaster must correlate them with each of the stages of the conductor's work and take into account the peculiarities of the conductor's activity of a music teacher.

Thus, based on the content of the conductor's creative activity and the general structure that has been established over the years, we have identified the following stages in the implementation of conductor training of future secondary school teachers.

1. Planning and drawing up of individual work plans of students. The course «Choral conducting» is designed for students who have prior training in the scope of children's music school, which meets the conditions of professional training of future music teachers. At the same time, there are students who have previous training within the music school. This requires the implementation of differentiated teaching of conducting, which requires the selection of educational repertoire with careful consideration of the individual capabilities and abilities of each student.

2. Study of the work and its comprehensive analysis. In the process of working on musical works, the conducting program should include the following aspects: information search about the work and its authors by the student; analysis of the literary text, study of the content, theme, artistic images of the work, the completeness of the composer's use of the text of the literary work, determining the degree of correlation of music with the content of the literary work; analysis of musical form: definition of musical form: phrasing, sentence, period, parts, size of work, meter, rhythmic structure, nature of melodic development, rhythmic pulsation; determination of tempo, ladotonal analysis (basic key, possible deviations, modulations), determination of work texture, dynamic indicators, type and type of work, system, range of choral parts, diction, breathing and other characteristics.

3. Conductor's interpretation of the work and determination of the method of studying the work with the performing team. During all years of study it is necessary to conduct purposeful work on individual musical and technical development of the student. Conducting is a kind of translation of music into the language of movements. The musical images conceived by the composer are heard and understood by the conductor with his inner hearing, they must be transmitted in sign language, that is made visible and understandable for the performers, because the members of the choir reproduce the interpretation of the composer's plan. That's why, systematic work in the conducting class should be carried out simultaneously in two directions: the study of the basics of conducting technique and the basics of practical work with the choir, which are combined in a single conducting process during learning and artistic performance of a musical work with a choir. Therefore, the main tasks of this stage of the educational process are: vocal analysis of choral parts of musical works of the planned program; determining the features of the conductor's gesture; analysis of possible vocal and choral difficulties; identifying performance difficulties and identifying ways to overcome them; definition of the executive plan; development of methods of working with the choir.

4. Conducting work with a choir includes such stages of work as: planning and compiling a thematic repertoire and public performance of a musical work by a choir. The stage of planning and compiling the thematic repertoire involves a clear definition by the teacher of the purpose of the choir's performances. According to this, the choir's repertoire is planned, taking into account the artistic significance, aesthetic requirements of the listeners, the performance capabilities of the artistic team and the conductor. At this stage, the developed method of working with the executive team is implemented in a practical aspect. Vocal and choral skills, choral skills of technical and performing work on the repertoire are formed and improved, the auditory reaction to the reproduced score is developed, the method of communication with the choir is practiced. The stage of public performance of a musical work involves the organization of a public performance of the performing team in accordance with the program. In the process of performing a musical and choral work, the conductor needs full concentration of attention, will, memory, imagination, thoughts, feelings, conducting skills, as well as the realization of the artistic image by means of conducting technique. It is realized through the ability to manage the team of performers by means of conducting gestures, the ability to evoke in them feelings, thoughts and will.

According to the methodological concepts of choral formation in the process of conducting and choral education of future art teachers, which were highlighted above, a formative experiment was conducted, the purpose of which was to determine the 
features of choral formation as an artistic and performing phenomenon. The experimental study was conducted on the basis of Bohdan Khmelnytsky Melitopol State Pedagogical University among students of I-IV courses and took place in four stages. At the initial stage of the research work, the ascertaining (diagnostic) section was performed among first-year students. The purpose of the ascertaining experiment was to determine the current state of the choir (mixed choir) of the institution of higher education. At this stage, it was important to identify difficulties in effectively organizing the activities of the student choir. Students were divided into two groups: control (students of III-IV courses) and experimental (students of I-II courses). This stage aimed to determine the level of vocal and choral skills and their place and role in the formation of the choir in the process of conducting and choral education. At the initial stage, research methods such as observation, interviews, testing, questionnaires were used. As part of the testing method, 4 methods were used: methods of studying the psychological climate in the team; questionnaire on the study of socio-psychological climate in the team; analysis and assessment of the psychological climate in the team; assessment of the psychological atmosphere in the team A.F. Fidler.

The second stage (information-orientation) is aimed at aesthetic education of members of the student choir, to improve their general cultural level, to develop interests and tastes in musical choral art. At the information-orientation stage we applied the methodical system of forming a choir in the process of conducting and choral education of future art teachers. The methodological system developed by us included pedagogical principles of conducting and choral training of future art teachers to create and lead a choir and psychological and pedagogical conditions for the formation of a choir. The discipline «Choral class» was conducted in the following forms: lectures, conversations, listening to audio recordings of choral works performed by leading choirs. Especially at this stage were methods aimed at the development of emotional and volitional sphere and cognitive activity of students, which increased the motivation of participants to the choral art, to enrich their spiritual potential.

The third stage (content-technological) provided for the acquisition and implementation by students of the necessary music-theoretical knowledge of choral art, practical skills and singing skills in working on a diverse repertoire. At this stage, the following forms of work were used: individual lessons, group rehearsals, work on the composition, analysis of choral works. The dominant methods of work were explana- tion, illustration, reproduction, combined exercises, reading from a sheet, creative tasks aimed at «immersion» in the content of each activity of the choir and giving freedom of creativity to all performers. Crucial at this stage were the activation of previously acquired theoretical knowledge and acquired practical skills of choral singing; stimulating students' independence in solving issues of choral life; improving the co-creation of all subjects of the creative process; expansion of communicative processes between participants of creative interaction; mastering the necessary practical skills in choral singing in working on the choral repertoire. It should be emphasized that these tasks are freely integrated, interacting with other types of artistic and creative activities of the team.

At the fourth stage (generalizing-realization) research the all substructures of the organization and successful functioning of choral collective as art and performing phenomenon were confirmed by us, and also the basic principles of conducting and choral preparation of future teachers of art to creation and management of choral collective and psychological and pedagogical conditions for the formation of the choir were confirmed. Integrative methods were used such as: discussions, strategies of one's own behavior, comparison, subordination, consideration of opinions, etc., and a study «Study of team cohesion» was conducted. The essence of this technique is as follows: all members of the group are asked to indicate ten positive and negative characteristics of a significant phenomenon for the group (for example, their leader, the features of their team, their joint activities, group prospects, etc.). Then, based on their answers, two sets of positive and negative characteristics are compared so that they include characteristics named by at least one of the group members. Each member of the group is asked to choose from these sets of five positive and negative characteristics that they consider the most positive (valuable) and the most negative (unnecessary).

The analysis of the results of the study «Study of choir cohesion» is carried out by counting the number of choices for each characteristic. Indicators of value-oriented unity (VOU), cohesion separately for the election of positive and negative characteristics are determined by the formula:

$$
\mathrm{VOU}=\frac{(\mathrm{n}-\mathrm{m}) * 100}{N}
$$

VOU $-\%$ cohesion of the group in relation to this object of assessment; $\mathrm{n}$ - the sum of the elections per five characteristics that received the maximum number of elections; $\mathrm{m}$ - the sum of the elections for the 
five characteristics that received the minimum number of elections; $\mathrm{N}$ - the total number of elections made by members of this group. The group with the maximum possible VOU is determined if all participants choose the same characteristics. Group with the minimum possible VOU (complete absence of value-oriented unity) - the tested persons do not prefer any of the above characteristics.

In conducting the experiment, we proceeded from the assumption that the choir as an artistic and performing phenomenon has a number of substructures necessary for its organization and successful operation, namely: organizational substructure, which is responsible for the activities of the group, the choice of purpose and direction of musical performance, methodological planning and selection of the repertoire, control and evaluation of the quality of the performance of choral works; axiological substructure, the vocation of which is to promote the spiritual heritage of choral art; creative and performing substructure, which is responsible for the forms of rehearsal work of the choir and the creation of a favorable creative microclimate; communicative substructure that adjusts relationships and forms; moral and ethical substructure, the task of which is to maintain psychological well-being, the formation of adequate self-esteem, ethical development of each member of the student choir; value-oriented substructure, the purpose of which is to promote cohesion, compatibility and ensemble work of team members; external substructure, responsible for contacts between groups, participation in various choral competitions and festivals.

The method of pedagogical experiment was introduced in the experimental group of students of I-II course of mixed choir of Bohdan Khmelnytsky Melitopol State Pedagogical University (EG, number of students -17 persons) and on the basis of comparative analysis the control group of students of III-IV course of mixed choir of Bohdan Khmelnytsky Melitopol State Pedagogical University (CG, number of students -27 persons). The analysis obtained as a result of these pedagogical tests showed positive changes in the levels of active participation of students in the formation of the choir in the process of conducting and choral education and confirmed the effectiveness of the developed step-by-step method of organizing student choir. The dynamics of changes in the levels of active participation of students in the activities of the choir of the control and experimental groups is shown in the diagram. After conducting research «Study of choir cohesion» it was possible to identify the most positive (valuable) and most negative (unnecessary) signs of choir cohesion. Positive signs are understanding, organization, activity, cohesion, diligence.
At the average stage of the study with students of the control and experimental groups were again conducted diagnostic techniques for the presence of the choir, the results of which are shown in the diagram. After processing the results of the survey, a positive upward trend was found for the high and medium levels of choir formation. In our opinion, such changes in indicators to increase the level of the choir formation are due to the fact that the second stage was aimed at aesthetic education of student choir members, to increase their general cultural level, to develop interests and tastes in musical choral art. Especially active at this stage were methods aimed at the development of emotional and volitional area and cognitive activity of students, which increased the motivation of participants to the choral art, to enrich their spiritual potential.

At the third stage of the research work, the students of the control and experimental groups were again offered methods for determining the formation of a choir. The results of the choir formation in the process of conducting and choral education with students from the experimental and control groups at the initial and final stages of the experimental research are shown in the diagram.

The results comparison of determining the choral formation methods at the initial and final stages makes it possible to trace the following dynamics of changes in the state of choir formation in the process of future art teachers conducting and choral education: students of the experimental group have a significant decrease in low levels (from $37.2 \%$ to $4.2 \%$ ); the average level changes in the direction of increasing indicators due to changes in the "low level" data (from $55.7 \%$ to $70.3 \%$ ); high level also has the dynamics of increase due to the decrease of indicators of "low level" and changes in data of "middle level" (from $7.1 \%$ to $25.5 \%$ ). The students of the control group have slight dynamic changes: highlevel indicators have a small increasing movement (from $10.5 \%$ to $15.3 \%$ ); average indicators increased slightly (from $60.3 \%$ to $65 \%$ ); 5 students of the control group remained at a low level of team formation, although in general in the period from the initial to the intermediate stage of the research there is a slight decrease in indicators (from $29.2 \%$ to $19.7 \%$ ) of the low level.

Based on the analysis of the musical and pedagogical heritage of leading figures of musical and choral culture, we have identified the basic principles of conducting and choral education of future art teachers. The principle of systematization presupposes the students training in the conditions of the pedagogical system structural components interconnection in gen- 


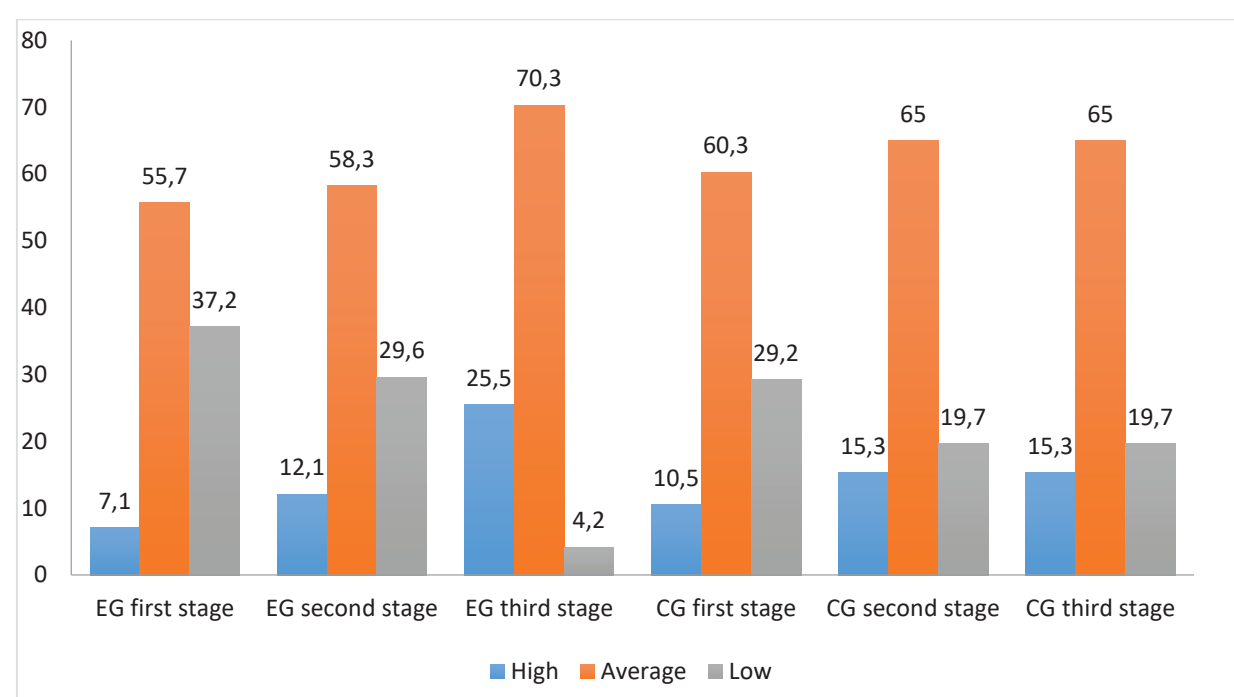

Figure 1. The results comparison of determining the choral formation methods at the initial and final stages

eral. It is seen as the integrity of the interdisciplinary links of the educational process, a comprehensive approach to teaching and educating the personality of the music teacher. The following principle of self-organization directs the system of conducting and choral education to self-development due to its internal self-activity. Requires consideration of self-organization of students' educational activities. The principle of fundamentalization and professionalization of conducting and choral education includes the formation of a specialist in educational institutions and provides a combination of his fundamental and professional training.

We managed to prove the educational functioning of these principles by conducting a survey of students of III-IV courses on the following content of the questionnaire, in which the task for students was to evaluate the following personal characteristics of teachers of the Department of theory and methodology of music education and choreography: communication based on interest in joint activities; the presence of a teacher's needs and ability to communicate; flexibility, sociability; operational and creative thinking; developed verbal abilities; the ability to feel and maintain feedback in communication, to manage their mental state even in an unprepared situation; friendliness and position of the senior colleague; developed reflection as a continuous rigorous analysis of their own activities; pedagogical improvisation for the fastest reactions to changes in the situation; positive interpersonal relations between the subjects of individual and group (choral) communication; awareness of the importance and educational significance of joint educational and extracurricular activities; stimulating optimism, sense of humor and the ability to be unusual and amazing; the presence of a rich in content subconscious and developed imagination.

Conclusions. The results of our research give grounds to claim that the application of modern principles and psychological and pedagogical conditions by the teachers of the department gives the most important result - the student's awareness of the personal significance of obtaining professional knowledge. It is to achieve such a result as the core direction of personal development of the future singer, conductor, art teacher aimed at modern higher art education. Thus, the obtained results showed the effectiveness of the implementation of the proposed methodological system of choir formation in the process of conducting and choral education of future art teachers. The practical significance of the research is that theoretical conclusions and experimental data can serve as a basis for improving the methodological foundations of the choir formation in the process of conducting and choral education of future art teachers. The materials presented in the work, as well as the developed methodical system of choir formation in the process of conducting and choral education of future art teachers can be used in further research on the problems of theory and methods of conducting.

\section{СПИСОК ВИКОРИСТАНИХ ДЖЕРЕЛ}

1. Канерштейн М.А. Питання диригентської майстерності. К.: Україна, 1980.

2. Коваленко І.Г. Сучасні підходи в диригентсько-хоровій підготовці майбутніх учителів музики. Наукові записки. Ніжин, 2002. № 1. С. 60-62. 
Pereverzeva E. Methodological fundamentals of formation of choir team in the process of conductor...

3. Костенко Л.В., Шумська Л.Ю. Формування хормейстерських умінь у класі хорового диригування: метод. рекомендації. Ніжин, 2005.

4. Сегеда Н.А. Професійний розвиток викладача музичного мистецтва: історія, методологія, теорія: монографія. K., 2011.

5. Сегеда Н.А. Самостійна підготовка студента до музично-педагогічного практикуму у хоровому класі. Методичні рекомендації. Мелітополь, 2012.

6. Смирнова Т.А. Теорія та методика диригентсько-хорової освіти у вищих навчальних закладах: психолого-педагогічний аспект: Монографія. Горлівка: «Видавництво Ліхтар», 2008.

\section{REFERENCES}

1. Kanerstein M. A. (1980) Pytannia dyryhentskoi maisternosti [Questions of conducting skills]. Kyiv [in Ukrainian].

2. Kovalenko I. G. (2002) Suchasni pidkhody v dyryhentsko-khorovii pidhotovtsi maibutnikh uchyteliv muzyky. [Modern approaches in conducting and choral training of future music teachers]. Naukovi zapysky, Nizhyn, № 1, pp. 60-62 [in Ukrainian].

3. Kostenko L.V., \& Shumska, L. Yu. (2005) Formuvannia khormeisterskykh umin u klasi khorovoho dyryhuvannia: metod. rekomendatsii. [Formation of choir skills in the class of choral conducting: method. Recommendations]. Nizhyn [in Ukrainian].

4. Segeda N.A. (2011) Profesiinyi rozvytok vykladacha muzychnoho mystetstva: istoriia, metodolohiia, teoriia: monohrafiia. [Professional development of a music art teacher: history, methodology, theory: monograph]. Kyiv [in Ukrainian].

5. Smirnova T.A. (2008) Teoriia ta metodyka dyryhentsko-khorovoi osvity u vyshchykh navchalnykh zakladakh: psykholoho-pedahohichnyi aspekt: Monohrafiia [Theory and methods of conducting and choral education in higher educational institutions: psychological and pedagogical aspect: Monograph]. Horlivka, «Vydavnytstvo Likhtar» [in Ukrainian]. 